\title{
Musa balbisiana and Musa paradisiaca Starches Increase SCFA and Caspase-3 as well as Decrease $\beta$-glucuronidase and MDA of Mouse Model for Colon Cancer
}

\author{
Diana Nur Afifah ${ }^{1}$, Fauzia Purnamasari ${ }^{1}$, Luthfiatul Khusna ${ }^{1}$, Noviasti Rahma Utami ${ }^{1}$, \\ Aida Fitri Nazillah ${ }^{1}$, Syafira Noor Pratiwi ${ }^{1}$, Fillah Fithra Dieny ${ }^{1}$, Aryu Candra ${ }^{1}$, Ayu Rahadiyanti ${ }^{1}$, \\ Rachma Purwanti ${ }^{1}$, Enny Probosari ${ }^{1}$, Martha Ardiaria ${ }^{1}$, Nyoman Suci Widyastiti ${ }^{2}$, Ferry Sandra ${ }^{3, *}$ \\ ${ }^{1}$ Department of Nutrition Science, Faculty of Medicine, Universitas Diponegoro, Jl. Prof. Sudarto No.13, Tembalang, Semarang 50275, Indonesia \\ ${ }^{2}$ Department of Clinical Pathology, Faculty of Medicine, Universitas Diponegoro, Jl. Prof. Sudarto No.13, Tembalang, Semarang 50275, Indonesia \\ ${ }^{3}$ Department of Biochemistry and Molecular Biology, Division of Oral Biology, Faculty of Dentistry, Universitas Trisakti, J1. Kyai Tapa No. 260, \\ Jakarta, Indonesia \\ *Corresponding author. E-mail: ferry@trisakti.ac.id
}

Received date: Jun 22, 2020; Revised date: Jan 6, 2021; Accepted date: Jan 18, 2021

\section{Abstract}

$\mathrm{B}$ ACKGROUND: Administration of resistant starch (RS) influences the diversity and the composition of microbiota as well as inhibits the growth of cancer cell. Banana as a potential source of RS has been reported. Although Musa paradisiaca has been reported to induce apoptosis in colon cancer cells, Musa balbisiana, which has low glycemic index and suitable for particular patients, has not been investigated yet.

METHODS: Starches of M. balbisiana and M. paradisiaca were prepared and mixed with other components to make 3 types of mouse pellets. Mouse model for colon cancer was prepared and fed with different types of mouse pellets. Blood was collected and processed for measuring $\beta$-glucuronidase and malondialdehyde (MDA) with Enzyme-linked Immunosorbent Assay (ELISA) method. Resected ceca were incised to collect the inner part for short-chain fatty acid (SCFA) measurement with gas chromatography analysis. Resected colas were

\section{Introduction}

About $80 \%$ of colon cancer causes were related to diet (1), due to higher consumption of animal protein and lower consumption of fiber.(2,3). Resistant starch (RS), a type of fiber, can prevent colon cancer.(4,5) Administration of RS influences the diversity and the composition of microbiota fixed and processed for immunohistochemistry to detect Caspase-3.

RESULTS: Colon-cancer-mice fed with the M. balbisiana and $M$. paradisiaca starches-contained pellets had significant higher concentrations of total SCFA ( $p=0.003)$, acetic acid $(p=0.000)$, propionic acid $(p=0.000)$ and butyric acid $(p=0.000$ ); lower concentration of $\beta$-glucuronidase $(p<0.001)$; higher Caspase-3 score $(p=0.040)$; and lower MDA concentration $(p<0.001)$ than colon-cancer-mice fed with standard pellet (control).

CONCLUSION: $M$. balbisiana and $M$. paradisiaca starches could be suggested as potential anti-colon cancer RS. Further research should be carried out to disclose the starches mechanisms in colon cancer cell.

KEYWORDS: Musa balbisiana, Musa paradisiaca, colon cancer, resistant starch, Caspase-3, SCFA, $\beta$-glucuronidase, malondialdehyde

Indones Biomed J. 2021; 13(1): 91-6

as well as increases the production of short-chain fatty acids (SCFA).(6)

SCFA acts as the energy source for the normal colon cell and the growth inhibitor for the cancer cell.(7) Lactic acid bacteria-fermented $\mathrm{RS}$ in colon can lower the $\mathrm{pH}$ to inhibit the activity of the $\beta$-glucuronidase enzyme. The $\beta$-glucuronidase enzyme releases the methylazoxymethanolglucuronic acid (MAM-GlcUA), which can turn into a free 
carcinogen in the form of free MAM. The free MAM will be concentrated on the colonic mucosa which then triggers the cancer growth.(8)

Butyric acid, a part of SCFA, can increase the activity of Caspase-3 which plays an important role in apoptosis. (9) Caspase 3 and its family have been widely investigated as the target for inducing apoptosis in tumor cells.(10-12) Addition of RS as high amylose maize starch has been reported due to its capability in increasing apoptosis and reducing proliferation of the colon cancer epithelial cell. (7) Besides that, butyric acid has anti-inflammatory effect as well, the malondialdehyde (MDA) level in plasma and colonocytes can be decreased.(5) Therefore the damage of DNA in an epithelial cell which might impact the genetic mutation, can be decreased.(13)

Banana can be processed into starch, which can be stored and utilized as food ingredient. Among various types of bananas, Musa paradisiaca has a special advantage of having smooth texture and white.(14) This banana is mainly planted in Indonesia and available in the market. (15) Another type of bananas, Musa balbisiana, contains high RS with low glycemic index value.(15) which is more suitable for particular patients. Both M. paradisiaca and M. balbisiana are rich in polyphenols $(16,17)$, which have beneficial effect for health $(18,19)$.

Research regarding potential of $M$. paradisiaca against colon cancer cell has been reported. The $M$. paradisiaca extract was shown to induce apoptosis in HT29 cells.(20) However, potential of $M$. balbisiana against colon cancer cell has not been clearly examined. Since the flours of $M$. paradisiaca and M. balbisiana might contain high potential against the colon cancer cell, current study was conducted.

\section{Methods}

\section{Mouse Banana Pellets}

The starches of $M$. balbisiana and M. paradisiaca were produced in the integrated laboratory of Universitas Diponegoro, Semarang. Briefly, the bananas were washed, peeled, minced, dried, blended, filtered, autoclaved, digested with $2 \%$ pullulanase, heat-inactivated, re-autoclaved and dried. Processed starches were mixed with other components to make 3 types of formulized pellets (Table 1).

\section{Animal Model and Treatment}

A post-test animal experimental study with control group design had been conducted from May to July 2019. Twenty male, aged 5-weeks old, weighted 19-33 g, healthy
Balb/c mice were acclimatized in The Animal Experiment Laboratory of Center for Food and Nutrition Studies, Universitas Gadjah Mada, Yogyakarta, with condition of $25-27^{\circ} \mathrm{C}, 40-70 \%$ humidity, $12 \mathrm{~h}$ light cycle, $5 \mathrm{~g}$ of standard AIN-93M and ad libitium drinking water for 7 days. After the acclimatization, the mice were injected intraperitoneally with/without azoxymethane (AOM) dissolved in $0.9 \%$ $\mathrm{NaCl}$ at a dosage of $0.01 \mathrm{mg} / \mathrm{g}$ body weight (BW).(21) Then the azoxymethane (AOM)-injected mice was fed intragastrically for 7 consecutive days with $2 \%$ dextran sodium sulfate (DSS) to speed up the occurrence of colon cancer. After that, the mice were observed and fed with $5 \mathrm{~g}$ of different formulized pellets based on the group division for 10 weeks (5 mice in each group). Negative control (NC) group was injected with $\mathrm{NaCl}$ merely and fed with pellets type 1. Positive control (PC) group was injected with AOM and intragastric DSS, then fed with pellets type 1 . Treatment 1 (T1) group was injected with AOM and intragastric DSS, then fed with pellets type 2 . Treatment 2 (T2) group was injected with AOM and intragastric DSS, then fed with pellets type 3. After the treatment, blood was collected, then the mice were sacrificed and resected for laboratory analyses. The research protocol has been approved by the Ethics Committee of Faculty of Medicine Universitas Diponegoro and dr. Kariadi Hospital (No. 33/EC/H/FCRSDK/IV/2019).

\section{SCFA Measurement}

Resected mice ceca were incised to collect the inner part for SCFA measurement. SCFA was measured in Food

Table 1. Type of formulized pellets with/without the flours of M. balbisiana and M. paradisiaca.

\begin{tabular}{lccc}
\hline \multirow{2}{*}{ Component } & \multicolumn{3}{c}{ Type of Pellets } \\
\cline { 2 - 4 } & $\mathbf{1}$ & $\mathbf{2}$ & $\mathbf{3}$ \\
\hline M. balbisiana $(\mathrm{g})$ & - & 19 & - \\
M. paradisiaca $(\mathrm{g})$ & - & - & 19 \\
Corn starch (g) & 46.57 & 43.07 & 43.07 \\
Casein (g) & 14 & 14 & 14 \\
Dextrin (g) & 15.5 & - & - \\
Sucrose (g) & 10 & 10 & 10 \\
Soybean oil (g) & 4 & 4 & 4 \\
Alphacel (g) & 5 & 5 & 5 \\
Mineral mix (g) & 3.5 & 3.5 & 3.5 \\
Vitamin mix (g) & 1 & 1 & 1 \\
L-Cystine (g) & 0.18 & 0.18 & 0.18 \\
Choline bitartrate (g) & 0.25 & 0.25 & 0.25 \\
\hline
\end{tabular}


Technology Laboratory of Universitas Gadjah Mada. The inner part of ceca was homogenized and prepared for gas chromatography analysis with CP-9002 (Chrompack, Middelburg, Netherlands). CP-9002 was equipped with RTX-Wax column (Chrom Tech, Apple Valley, MN, USA) to detect acetic acid, propionic acid, butyric acid and total SCFA.

\section{Enzyme-linked Immunosorbent Assay (ELISA)}

Blood was collected from plexus retro-orbitalis and processed to isolate plasma. Blood plasma was used as the sample to measure MDA. Meanwhile homogenized ceca was used and processed as the sample to measure $\beta$-glucuronidase. Measurements were performed in Center Biotechnology Studies of Universitas Gadjah Mada. For $\beta$-glucuronidase, Mouse Gusb (Beta-glucuronidase) ELISA Kit (Catalogue No. EM0350, Wuhan Fine Biotech, Wuhan, China) with sandwich method was used. Meanwhile for MDA, MDA ELISA Kit (Catalogue No. EU2577, Wuhan Fine Biotech) with competitive method was used. Both kits used 3,3',5,5'-Tetramethylbenzidine (TMB) substrates to visualize enzymatic reaction. For both detections, the optical density (OD) absorbance was read at $450 \mathrm{~nm}$ in a microplate reader.

\section{Immunohistochemistry}

Resected colas of all mice were fixed and processed for making the colon paraffin blocks. The paraffin blocks were sliced in $4 \mu \mathrm{m}$, de-paraffinized and antigen retrieved. After that, the tissue sections were incubated with 3\% hydrogen peroxide and then $0.1 \%$ skim milk. The $1: 150$ rabbit polyclonal anti-Caspase-3 antibody (Catalogue No. FNab01289, Wuhan Fine Biotech) was used as the primary antibody. Then Starr Trek Universal HRP Detection System (BioCare Medical, Pacheco, CA, USA) was used to bind to the primary antibody and to produce brown signals. Hematoxylin was used as the counterstaining. Immunohistochemical results were documented under a light microscope with 100x magnification. Cells with overexpression of Caspase-3 were examined and scored from 0 to 4 based on the distribution of signal/staining by 2 observers. Score 0: no signal; Score 1: 1-25\%; Score 2: $26-50 \%$, Score 3: $51-75 \%$, Score 4: 76-100\%. Immunohistochemistry was performed in Anatomical Pathology Laboratory of Universitas Sebelas Maret and Diponegoro National Hospital.

\section{Statistical Analysis}

Differences of the groups were determined by using the oneway ANOVA test when the data were normally distributed based on Shapiro Wilk test. When the data were abnormally distributed, Kruskal-Wallis test was used. Significancy was set at $p$-value $<0.05$. In addition, the post hoc test was used to find the significant difference between each group.

\section{Results}

\section{Total SCFA Concentration was Increased in T1 and T2 Groups}

Based on Table 2, PC group had the lowest concentration of acetic, propionic and butyric acids. Hence, total SCFA concentration of the PC group was also the lowest. T2 group had the highest concentration of total SCFA, acetic, propionic and butyric acids. The total SCFA, acetic, propionic and butyric acids concentrations of $\mathrm{NC}, \mathrm{T} 1$ and T2 groups were significantly higher than those of PC group.

\section{$\beta$-glucuronidase Concentration was Decreased in $\mathrm{T} 1$ and T2 Groups}

The $\beta$-glucuronidase concentration of $\mathrm{NC}$ group was the lowest, while the $\beta$-glucuronidase concentration of $\mathrm{PC}$

Table 2. SCFA concentration of all groups.

\begin{tabular}{ccccc}
\hline \multirow{2}{*}{ Group } & \multicolumn{4}{c}{ SCFA Concentration $(\mathbf{m M})$} \\
\cline { 2 - 5 } & $\begin{array}{c}\text { Acetic Acid } \\
(\text { Median }(\text { Min-Max) })\end{array}$ & $\begin{array}{c}\text { Propionic Acid } \\
(\text { Mean } \pm \text { SD) }\end{array}$ & $\begin{array}{c}\text { Butyric Acid } \\
(\text { Mean } \pm \text { SD) }\end{array}$ & $\begin{array}{c}\text { Total } \\
(\text { Mean } \pm \text { SD) }\end{array}$ \\
\hline NC & $115.29(108.72-143.82)^{\mathrm{a}}$ & $44.18 \pm 11.49^{\mathrm{ac}}$ & $12.67 \pm 3.32^{\mathrm{a}}$ & $179.30 \pm 30.77^{\mathrm{a}}$ \\
PC & $19.70(16.20-35.33)^{\mathrm{b}}$ & $8.15 \pm 4.24^{\mathrm{b}}$ & $2.36 \pm 1.22^{\mathrm{b}}$ & $33.43 \pm 13.06^{\mathrm{b}}$ \\
T1 & $85.87(81.74-135.21)^{\mathrm{c}}$ & $41.13 \pm 3.44^{\mathrm{a}}$ & $11.79 \pm 2.59^{\mathrm{a}}$ & $149.37 \pm 27.39^{\mathrm{a}}$ \\
T2 & $130.63(99.89-243.50)^{\mathrm{a}}$ & $51.34 \pm 4.34^{\mathrm{c}}$ & $20.67 \pm 6.78^{\mathrm{a}}$ & $230.82 \pm 72.85^{\mathrm{a}}$ \\
\hline$p$ & $0.003^{*}$ & $0.000^{*}$ & $0.000^{*}$ & $0.000^{*}$ \\
\hline
\end{tabular}

*Kruskall-Wallis test for acetic acid and One-way ANOVA test for propionic acid, butyric acid and total SCFA. a,b,c Post Hoc MannWhitney for acetic acid and Post Hoc Tamhane for propionic acid, butyric acid and total SCFA. 
Table 3. $\beta$-glucuronidase concentration, Caspase-3 score, MDA concentration of all groups.

\begin{tabular}{|c|c|c|c|c|c|c|}
\hline \multirow[t]{2}{*}{ Group } & \multicolumn{2}{|c|}{$\begin{array}{c}\beta \text {-glucuronidase Concentration } \\
(\mathrm{pg} / \mathrm{mL})\end{array}$} & \multicolumn{2}{|c|}{ Caspase-3 Score } & \multicolumn{2}{|c|}{$\begin{array}{l}\text { MDA Concentration } \\
(\mathbf{n g} / \mathbf{m L})\end{array}$} \\
\hline & Mean \pm SD & $p$ & $\operatorname{Mean} \pm$ SD & $p$ & $\operatorname{Mean} \pm$ SD & $p$ \\
\hline $\mathrm{NC}$ & $82.55 \pm 6.66^{\mathrm{a}}$ & \multirow{4}{*}{$<0.001 *$} & $3.86 \pm 0.11^{\mathrm{a}}$ & \multirow{4}{*}{$0.040 *$} & $7.69 \pm 0.64^{\mathrm{a}}$ & \multirow{4}{*}{$<0.001 *$} \\
\hline $\mathrm{PC}$ & $318.56 \pm 10.48^{\mathrm{b}}$ & & $2.20 \pm 0.87^{\mathrm{b}}$ & & $26.28 \pm 0.76^{\mathrm{b}}$ & \\
\hline $\mathrm{T} 1$ & $93.57 \pm 2.41^{\mathrm{a}}$ & & $2.93 \pm 0.11^{\mathrm{abc}}$ & & $8.75 \pm 0.29^{c}$ & \\
\hline $\mathrm{T} 2$ & $109.56 \pm 2.00^{\mathrm{c}}$ & & $2.66 \pm 0.11^{\mathrm{bc}}$ & & $10.07 \pm 0.18^{\mathrm{d}}$ & \\
\hline
\end{tabular}

*One Way ANOVA test. ${ }^{\mathrm{a}, \mathrm{b}, \mathrm{c}}$ Post Hoc Tukey.

group was the highest (Table 3 ). The $\beta$-glucuronidase concentration of $\mathrm{NC}, \mathrm{T} 1$ and $\mathrm{T} 2$ groups were significantly lower than those of PC group. Moreover, the $\beta$-glucuronidase concentration of T1 group was significantly lower than the concentration of T2 group (Post hoc Tukey, $p<0.05)$.

\section{Caspase-3 Score was Increased in T1 and T2 Groups}

As shown in immunohistochemical results, strong Caspase-3 immunohistochemical signals were seen in Figure 1A, Figure 1C and Figure 1D. The Caspase-3 score of NC group was the highest, while the Caspase-3 score of PC group was the lowest (Table 3). The Caspase-3 score of NC group were significantly higher than those of PC and T2 groups. Although not significant, the Caspase-3 score of T1 group was higher than those of PC and T2 groups.

\section{MDA Concentration was Decreased in T1 and T2 Groups} The MDA concentration of NC group was the lowest, while the MDA concentration of PC group was the highest (Table 3 ). The MDA concentration of T1 group was significantly lower than the concentration of T2 group (Post hoc Tukey, $p<0.05)$.
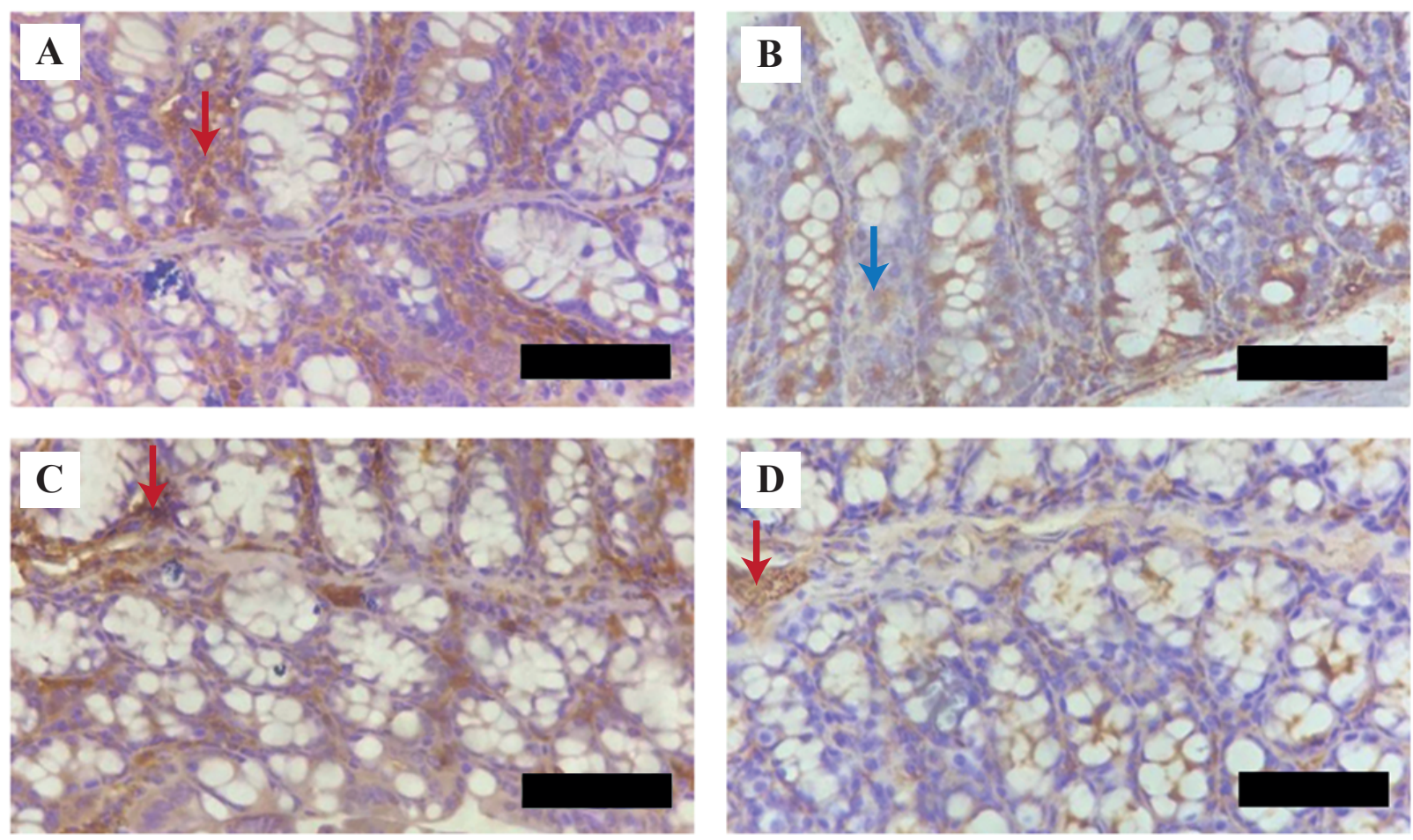

Figure 1. Caspase-3 immunohistochemical expression of Cola. Cola of NC (A), PC (B), T1 (C) and T2 (D) groups were immunohistochemical stained to detect Caspase-3. Red arrow: strong Caspase-3 immunohistochemical signal. Blue arrow: weak Caspase-3 immunohistochemical signal. Black bar: $100 \mu \mathrm{m}$. 


\section{Discussion}

The induction of AOM and DSS decreased the SCFA concentration. The low SCFA level is not only the biomarker for cancer risk, but also for the growth and severity of colon cancer.(22) As shown in Table 2, the total SCFA, acetic, propionic and butyric acids concentrations of $\mathrm{NC}$, $\mathrm{T} 1$ and T2 groups were significantly higher than those of PC group. All these acids were important. The acetic acid plays a role in increasing ileum motility, increasing blood flow to the colon, inducing the growth and development of adipose tissue, as well as in maintaining the immune system.(23) The propionic acid stimulates the proliferation of colonic epithelial, which can help to maintain cell lining integrity.(21) The butyric acid induces apoptosis as well as inhibits the growth of colon cancer cells, and stimulates the inflammatory response against colon cancer.(23)

M. balbisiana starch-contained pellet (T1 group) or M. paradisiaca starch-contained pellet (T2 group) can be fermented by lactic acid bacteria in the large intestine to produce SCFA.(24) The proportional increase of lactic acid bacteria in the intestine can decrease the concentration of the $\beta$-glucuronidase by suppressing the growth of $\beta$-glucuronidase-producing bacteria such as Escherichia coli and Clostridium perfringens. The $\beta$-glucuronidase production should be suppressed since $\beta$-glucuronidase can hydrolyze MAM-GlcUA to release free MAM, which is an active carcinogen.(25) Based on the present study, the $\beta$-glucuronidase concentration of AOM and DSS-induced mice could be reduced significantly by feeding the mice with $M$. balbisiana starch-contained pellet (T1 group) or $M$. paradisiaca starch-contained pellet (T2 group). Moreover, the post-hoc test showed that there was no significant difference between the $\beta$-glucuronidase concentration of the T1 and NC groups, suggesting that $M$. balbisiana starch could inhibit the production of $\beta$-glucuronidase, so that the concentration was almost equal to the $\beta$-glucuronidase concentration of the $\mathrm{NC}$ group. The present results were comparable with previous studies of sorghum treatment for the AOM and DSS-treated mice.(26)

Induction of cancer cells in to apoptosis has been well reported in many cancer researches.(11,27,28) In the present study, Caspase-3 scores were higher in T1 and $\mathrm{T} 2$ groups than PC group, suggesting that M. balbisiana starch (T1 group) or $M$. paradisiaca starch (T2 group) were crucial in apoptotic induction of colon cancer cells in this mouse model. SCFA, particularly butyric acid contained in both starches, has a role in increasing the expression and activation of Caspase-3, therefore triggering the apoptosis of colon cancer cells. $(4,29)$ A study on modified RS showed that the amylose content in M. balbisiana starch (17.77\%) was higher than that in M. paradisiaca starch (15.47\%). $(30,31)$ Amylose was more resistant to the digestive enzyme of the small intestine. Therefore, amylose could pass to the colon undigested, then be fermented by lactic acid bacteria to produce SCFA.(32)

$\mathrm{AOM}$ and DSS could induce the releasing of reactive oxygen species (ROS) by natural immune cell and leading to an increase in oxidative stress, which could be seen from the MDA level.(33) In present study, the MDA concentrations of $\mathrm{T} 1$ and $\mathrm{T} 2$ groups were significantly lower than the concentration of PC group. Propionic acid contained in the M. balbisiana and M. paradisiaca starches might play a role in reducing the synthesis of cholesterol and fatty acids which will lead to the decrease of ROS production, lipid peroxidation reduction, and low MDA production sequentially.(34) Besides propionic acid, the butyric acid could also reduce ROS and affect the activity of intracellular antioxidants, which can inhibit the enzyme that produces free radicals. and MDA levels.(35) Therefore, M. balbisiana and $M$. paradisiaca starches could be useful to reduce the MDA level.

\section{Conclusion}

Taken together, since M. balbisiana and $M$. paradisiaca starches had significant impact in increasing of SCFA concentration and Caspase- 3 as well as decreasing $\beta$-glucuronidase and MDA concentrations of $\mathrm{AOM}$ and DSS-induced mouse model for colon cancer, the starches could be suggested as potential anti-colon cancer RS. Further research should be carried out to disclose the starches mechanisms in colon cancer cell.

\section{Authors Contribution}

DNA and NSW were involved in concepting and planning the research. DNA, FP, LK, NR, AFN, SNP and NSW performed the data acquisition/collection, while FP, LK, NR, and AFN performed the data analysis. FFD, AC, AR, RP, EP, and MA interpreted the results. DNA and SNP drafted the manuscript, while FP, LK, NR, and AFN designed the table and figures. SNP and FS helped in giving critical revision of the manuscript. 


\section{References}

1. Leu RK Le, Brown IL, Hu Y, Morita T, Esterman A, Young GP. Effect of dietary resistant starch and protein on colonic fermentation and intestinal tumourigenesis in rat. Carcinogenesis. 2007; 28: 240-5.

2. Shusuke Toden, Bird AR, Topping DL, Conlon MA. Resistant starch prevents colonic DNA damage induced by high dietary cooked red meat or casein in rats. Cancer Biol Ther. 2006; 5: 267-72.

3. Winter J, Nyskohus L, Young GP, Hu Y, Conlon MA, Bird AR, et $a l$. Inhibition by resistant starch of red meat-induced promutagenic adducts in mouse colon. Cancer Prev Res. 2011; 4: 1920-8.

4. Purwani EY. Pati resistan serta perannya dalam penghambatan proliferasi dan induksi apoptosis sel kanker kolon. Indones $\mathrm{J}$ Cancer. 2014; 8: 173-7.

5. Toden S, Belobrajdic DP, Bird AR, Topping DL CM. Effects of dietary beef and chicken with and without high amylose maize starch on blood malondialdehyde, interleukins, IGF-I, insulin, leptin, MMP2, and TIMP-2 concentrations in rats. Nutr Cancer. 2010; 62: 45465.

6. Hu Y, Leu RKL, Christophersen CT, Somashekar R. Conlon MA, Meng XQ, et al. Manipulation of the gut microbiota using resistant starch is associated with protection against colitis-associated colorectal cancer in rats. Carcinogenesis. 2016; 37: 366-75.

7. Bauer-Marinovic $\mathrm{M}$, Florian $\mathrm{S}$, Müller-Schmehl $\mathrm{K}$, Glatt $\mathrm{H}$, Jacobasch G. Dietary resistant starch type 3 prevents tumor induction by 1,2-dimethylhydrazine and alters proliferation, apoptosis and dedifferentiation in rat colon. Carcinogenesis. 2006; 27: $1849-59$

8. Summart R, Chewonarin T. Purple rice extract supplemented diet reduces DMH-induced aberrant crypt foci in the rat colon by inhibition of bacterial $\beta$-glucuronidase. 2014; 15: 749-55.

9. Amini A, Khalili L, Keshtiban AK, Homayouni A. Resistant starch as a bioactive compound in colorectal cancer prevention. In: Probiotics, Prebiotics, and Synbiotics. Amsterdam: Elsevier Inc.; 2016. p. $773-80$.

10. Sandra F, Hendarmin L, Nakao Y, Nakamura N, Nakamura S. TRAIL cleaves caspase-8, -9 and -3 of AM-1 cells: a possible pathway for TRAIL to induce apoptosis in ameloblastoma. Tumour Biol. 2005; 26: $258-64$.

11. Sandra, F. Targeting ameloblatoma into apoptosis. Indones Biomed J. 2018; 10: 35-9.

12. Sandra F, Hudono KF, Putri AA, Putri CAP. Caspase inhibitor diminishes caffeic acid-induced apoptosis in osteosarcoma cells. Indones Biomed J. 2017; 9: 160-4.

13. Veljković A, Stanojević G, Branković B, Pavlović D. Parameter of oxidative stress in colon cancer tissue. Acta Medica Median. 2016; 55: 32-7.

14. Putri T, Veronika D, Ismail A, Kurniawan A, Maxiselly Y, Irwan A, et al. Pemanfaatan jenis-jenis pisang (banana dan plantain) lokal Jawa Barat berbasis produk sale dan tepung Utilization kind of local West Java bananas ( banana and plantain ) based figs and flour product. J Kultiv. 2015; 14: 63-70.

15. Musita N. Kajian kandungan dan karakteristiknya pati resisten dari berbagai varietas pisang. J Din Penelit Ind. 2012; 23: 57-65.

16. Anwer Z, Sharma K, Garg VK, Kumar N, Kumari A. Hypertension management in diabetic patients. 2011; 15: 1256-63.

17. Zulkifli B, Akmal M, Wahyuni S, Siregar TN, Gholib G. Identification of active compounds of kepok banana peel and the effect on testosterone concentration in male rats with high-fat diet. E3S Web Conf. 2020; 151: 1-5.
18. Bhandarkar NS, Brown L, Panchal SK. Chlorogenic acid attenuates high-carbohydrate, high-fat diet-induced cardiovascular, liver, and metabolic changes in rats. Nutr Res. 2019; 62: 78-88.

19. Agunloye OM, Oboh G, Ademiluyi AO, Ademosun AO, Akindahunsi AA, Oyagbemi AA, et al. Cardio-protective and antioxidant properties of caffeic acid and chlorogenic acid: Mechanistic role of angiotensin converting enzyme, cholinesterase and arginase activities in cyclosporine induced hypertensive rats. Biomed Pharmacother. 2019; 109: 450-8.

20. Arun KB, Madhavan A, Reshmitha TR, Thomas S, Nisha P. Musa paradisiaca inflorescence induces human colon cancer cell death by modulating cascades of transcriptional events. Food Funct. 2018; 9: 511-24.

21. Sharma A, Yadav BS. Resistant Starch : Physiological roles and food applications. Food Rev Int. 2008; 24: 193-234.

22. O'Keefe S. Diet, microorganisms and their metabolites, and colon cancer. Nat Rev Gastroenterol Hepatol. 2016; 13: 691-706.

23. Hong YH, Nishimura Y, Hishikawa D, Tsuzuki H, Miyahara H, Gotoh $\mathrm{C}$, et al. Acetate and propionate short chain fatty acids stimulate adipogenesis via GPCR43. Endocrinology. 2005; 146: 5092-9.

24. Zeng H, Lazarova DL, Bordonaro M. Mechanism linking dietary fiber, gut microbiota and colon cancer prevention. World J Gastrointest Oncol. 2014; 6: 41-51.

25. Chen J, Huang X. The signal pathways in azoxymethane-induced colon cancer and preventive implications. Cancer Biol Ther. 2009; 8: 1313-7.

26. Sadek NF. Pemberian Sorgum (Sorghum bicolor L. Moench) Menghambat Perkembangan Kanker Kolon Pada Mencit Balb/c Melalui Perbaikan Lingkungan Mikro Kolon. Bogor: Institut Pertanian Bogor; 2012.

27. Sandra F. Survivin ser81 plays an important role in PI3K/Akt/mTOR signaling pathway. Mol Cell Biomed Sci. 2018; 2: 55-9.

28. Setiawan KW, Sandra F. Naïve $\mathrm{T}$ cells in immunosuppression diseases: human immunodeficiency virus and cytomegalovirus. Mol Cell Biomed Sci. 2018; 2: 1-10.

29. Zheng Y, Wang Q, Li B, Lin L, Tundis R, Loizzo MR, et al. Characterization and prebiotic effect of the resistant starch from purple sweet potato. Molecules. 2016; 21(7): E932. doi: 10.3390/ molecules21070932.

30. Afifah DN, Stephanie S, Aulia A, Rahadiyanti A, Kurniawatin DM, Rustanti N, et al. Physical and chemical characteristics of enzymatically modified Batu banana (Musa balbisiana Colla) and Kepok banana (Musa paradisiaca formatypica) flours. Food Research. 2020; 5: 124-31.

31. Avivi-Green C, Polak-Charcon S, Madar Z, Schwartz B. Different molecular events account for butyrate-induced apoptosis in two human colon cancer cell lines. J Nutr. 2002; 132: 1812-8.

32. Liu XH, Ye CX, Ye JD, Shen BD, Wang CY, Wang AL. Effects of dietary amylose/amylopectin ratio on growth performance, feed utilization, digestive enzymes, and postprandial metabolic responses in juvenile obscure puffer Takifugu obscurus. Fish Physiol Biochem. 2014; 40: 1423-36.

33. Adhika OA. Phytopreventive effect of buah merah (Pandanus conoideus Lam.) oil in colitis-associated carcinogenesis. J Med Heal. 2015; 1: 126-42.

34. Puspitasari S, Syauqy A. Pengaruh pemberian pisang kepok (musa paradisiaca forma typical) terhadap kadar malondialdehyde (mda) tikus sprague dawley pra-sindrom metabolik). JNC. 2015; 4: 31422.

35. Hamer HM, Jonkers DMAE, Bast A, Vanhoutvin SALW, Fischer MAJG, Kodde A, et al. Butyrate modulates oxidative stress in the colonic mucosa of healthy humans. Clin Nutr. 2009; 28: 88-93. 